\title{
PROTOPLAST AS A TOOL TO ADDRESS QUESTIONS IN PLANT PHYSIOLOGY
}

\author{
${\underline{\operatorname{Tim}} \mathrm{XING}^{1 *}, \text { Lining TIAN }}^{2}$ \\ ${ }^{1}$ Department of Biology and Institute of Biochemistry, Carleton University, Ottawa - Canada K1S 5B6 \\ ${ }^{2}$ Agriculture and Agri-Food Canada, London Research and Development Centre, London, ON - \\ Canada N5V 4T3 \\ * Corresponding author. E-mail: tim.xing@ carleton.ca
}

\begin{abstract}
A protoplast is a plant cell from which the cell wall has been removed by enzyme treatment. Tremendous utilization of protoplast in molecular analysis of plant growth and development has been observed in the past decades and the system has paved its way to significantly facilitate the comprehensive understanding of the complexity of underlying mechanisms. However, it should be kept in mind that a plant, like all systems, is composed of networks of interdependent components that integrate the system into a unified whole. In this mini review, we will re-explore protoplast approach in answering plant physiology questions through discussion of its application in the study of (1) photosynthesis and chloroplast-related process; (2) pollen tube growth; (3) sieve tube element protoplast for long distance translocation; (4) new regulatory metabolites from guard cell protoplast. This in vitro approach may open the way to further meaningful results at organismal level.
\end{abstract}

Key Words: guard cell, pollen tube, protoplast, photosynthesis, sieve tube element, stomata.

\section{Introduction}

Protoplasts are plant cells that are not enveloped by the protective cell wall. Physiological properties of plant protoplasts and application of plant protoplasts as a physiological tool were discussed a few decades ago reflecting the early purpose and effort of the use of protoplasts [GALUN, 1981; PILET, 1985]. With the advance in cellular and molecular technology, protoplast application in the analysis of plant signaling has been reemphasized [SHEEN, 2001; XING \& WANG, 2015; XING \& al. 2017]. Educational effort was made through Annual Conference of American Society of Plant Biologists and published protocols are provided by Sheen Lab [http://molbio.mgh.harvard.edu /sheenweb/protocols_reg.html].

The concerns and drawbacks in using protoplasts for plant studies are mainly related to the single cell status isolated from in planta environment and the potential damage due to the isolation process [SHEEN, 2001]. Plant cell metabolism, growth, and development are modified by a large variety of internal and external signals. The ability of cells to respond to these signals is not confined to cells that are still growing and developing. Mature cells too can initiate metabolic responses and can even reinitiate growth and division in response to signal information. Many regulatory pathways are now characterized and the underlying genes are known. However, we should admit that contrast to animal cells, plant cells can easily change their identity when taken out of their environment or when cell lineages are disrupted [FARACO \& al. 2011]. They may even change identity rapidly according to their new position when they are re-positioned [VAN DEN BERG \& al. 1995]. Another indication comes with the totipotency and regeneration 
of an entire plant from cultured protoplasts as they must have first gone through dedifferentiation. It is not unreasonable to consider protoplasts as cells with loss of their identity and it makes protoplasts questionable in studies of cell type or tissue specific processes [FARACO \& al. 2011].

On the other hand in this regard, two of the most significant supporting evidences are also provided in previous discussions: (1) Protoplasts retain properties of the cells and tissues they originate from for hours [BART \& al. 2006; BIRNBAUM \& al. 2003; FARACO \& al. 2011; SHEEN, 2001; ZHAI \& al. 2009]; (2) Protoplasts may have similar responses as intact whole plant tissues when responding to hormones, metabolites and environmental stimuli, and early experiments verified protoplast involvement in active photosynthesis and respiration, and protoplast retained their cell membrane potentials as endogenous cells [SHEEN, 2001]. Protocols have been well established for a large variety of plant species, so potentially some specific physiological functions could be tested in these species using protoplasts [XING \& WANG, 2015]. Here, we will re-emphasize its usefulness in addressing physiological questions in plants through discussion of some representative cases.

\section{Photosynthesis and chloroplast-related process}

Biological process can often be a relay of events occurring from one specific tissue or cell type to another. While this could be a disadvantage for protoplast application, there are studies with cells which have specific functions but are surrounded by other cells that may interfere with these studies. The usefulness of protoplast techniques for physiological investigations is especially evident in physiological studies of photosynthetically active leaf cells.

The $\mathrm{C}_{4}$ photosynthetic carbon cycle is evolved as an adaptation to high light intensities, high temperatures, and dryness, and it can be considered an elaborated addition to the $\mathrm{C}_{3}$ pathway. The evolution also introduced biochemical and anatomical modifications that allow plants with this photosynthetic pathway to concentrate $\mathrm{CO}_{2}$ at the site of ribulose-1,5-bisphosphate carboxylase/oxygenase (Rubisco), thereby its oxygenase reaction and the following photorespiratory pathway are largely repressed in $\mathrm{C}_{4}$ plants [GOWIK \& WESTHOFF, 2011]. In most $\mathrm{C}_{4}$ plants the $\mathrm{CO}_{2}$ concentration mechanism is achieved by a division of labor between two distinct, specialized leaf cell types, the mesophyll and the bundle sheath cells [EDWARDS \& al. 2004]. The bundle sheath cells enclose the vascular bundles and are themselves surrounded by the mesophyll cells. This wreath-like structure of $\mathrm{C}_{4}$ leaf anatomy is termed Kranz anatomy, which is absent in $\mathrm{C}_{3}$ plants. In the early attempt, protoplasts were isolated from mesophyll cells of $\mathrm{C}_{3}$ plants and mesophyll protoplasts were separated from bundle sheath cells of $\mathrm{C}_{4}$ plants [cf. GALUN, 1981]. It was shown that the carboxylation phase of the $\mathrm{C}_{4}$ pathway is located in mesophyll protoplasts while the decarboxylative phase of this pathway as well as the carboxylative phase of the Calvin-Benson pathway is located in the bundle sheath cells. Ribulose-1,5-bisphosphate carboxylase was found only in bundle sheath cells and not in mesophyll protoplasts [cf. GALUN, 1981].

To further our understanding of sophisticated underlying regulatory mechanisms, a highly efficient rice green tissue protoplast system for studying light/chloroplast-related processes was established [ZHANG \& al. 2011]. The feasibility of such studies was demonstrated by the observation that transient expression of the GFP tagged light-related transcription factor OsGLK1 markedly upregulated transcript levels of the endogenous photosynthetic genes OsLhcb1, OsLhcp, GADPH and RbcS [ZHANG \& al. 2011]. 


\section{Pollen tube growth}

Pollen recognition or rejection is determined by the pollen surface protein and stigma surface protein. The process involves fluxes of multiple ions. The use of noninvasive methods has demonstrated a close link between intracellular ion fluctuations and ionic fluxes across the plasma membrane, and the cellular phenomena that occur during the formation and elongation of the pollen tube [FEIJÓ \& al. 2001; HEPLER \& al. 2001]. Transcriptomic studies have also demonstrated a number of anion /chloride membrane transporters and channels to be specifically and highly expressed in the pollen of Arabidopsis [PINA \& al. 2005]. Protoplasts are favorable tools to study transport physiology as well as other physiological entities of the plasma membrane. The study in in the plasma membrane of Lilium longiflorum pollen protoplasts showed for the first time the presence of a large anionic conductance across the membrane of pollen protoplasts, resulting from the presence of $\mathrm{Ca}^{2+}$-regulated channels, and a similar conductance was also found in germinated pollen [TAVARES \& al. 2011].

\section{Sieve tube element protoplast for long distance translocation}

It is arguable whether protoplast approach is applicable to some highly coordinated physiological processes. One of the examples is phloem long distance translocation. In angiosperms, sieve elements (SE) lose many organelles, retaining only the plasma membrane and modified mitochondria, plastids, and smooth endoplasmic reticulum. Sieve elements are interconnected through pores in their end cell walls and form a longitudinal series called sieve tube. Companion cells aids the highly specialized sieve elements in three main ways (1) transport photosynthetic products from producing cells in mature leaves to the sieve elements in the minor veins of the leaf; (2) carry the protein synthesis, that is reduced/lost in sieve elements; and (3) supply ATP to sieve elements. The pressure-flow model explains phloem translocation as a bulk flow of solution driven by an osmotically generated pressure gradient between source and sink. These sieve element cells are transporting cells but with specialized subcellular structures. While protoplasts have yielded considerable insight into plasma membrane-bound ion channels and carbohydrate carriers in a variety of plant cells ranging from large parenchyma cells to guard cells, due to technical barriers, SEs were missing from other cell types that had been protoplasted successfully.

A technical fine tuning of cell wall digestion and the unequivocal identification of SE protoplasts led to isolation of functional SE protoplasts from Vicia faba as tested by osmotic treatment and the functionality examined by patch-clamp experiments [HAFKE \& al. 2007]. At negative membrane voltages, the current-voltage relations of the SE protoplasts were found dominated by a weak inward-rectifying $\mathrm{K}^{+}$channel that was active at physiological membrane voltages of the SE plasma membrane [HAFKE \& al. 2007]. This channel had electrical properties that are reminiscent of those of the AKT2/3 channel family, localized in phloem cells of Arabidopsis [DEEKEN \& al. 2002; LACOMBE \& al. 2000]. SE protoplasts could be an alternative in studying the membrane biology of SEs with inherent implications for the understanding of long distance transport and signaling. SEmediated mass flow through phloem makes high demands on the physical properties of the SE plasma membrane, and isolation of SE protoplasts may thus facilitate the study of membrane biophysics in this long distance process [PATRICK, 2013; TURGEON \& WOLF, 2009]. 
Phloem-associated $\mathrm{K}^{+}$channels had been located in the phloem by in situ analysis [LACOMBE \& al. 2000], however, the exact cellular localization, ion channel densities, ion channel types, and particularly distribution along the phloem path were unknown. SE protoplasts isolated from the respective phloem sections would provide a unique tool for unequivocal information about these issues. Such successive phloem sectioning also enabled to identify, characterize, and quantify carbohydrate carriers in the SE plasma membrane at various sites along the phloem translocation pathway. Differential deployment of sugar carriers is likely essential for carbohydrate allocation in intact plants [HAFKE \& al. 2007; KÜHN, 2003; PATRICK, 2013].

\section{From metabolomics analysis of guard cell protoplast to leaf stomata bioassay}

Among the environmental signals that guard cells transduce are light quality, light intensity, intercellular concentrations of leaf carbon dioxide, drought, and apoplastic concentrations of abscisic acid (ABA) [OUTLAW, 2003]. Drought can severely damage crops and at physiological level, vascular land plants conserve water via stomatal closure in response to drought. Guard cells have been highly developed as a model system to dissect the dynamics and mechanisms of plant cell signaling as well as for studies on guard cell ion transport [OUTLAW, 2003; TALLMAN, 2006; ZHU \& al. 2016]. A recent comprehensive protocol on cellular, electrophysiological, and omics assays of guard cell function is a good reference [ZHU \& al. 2016]. Small scale and large scale guard cell protoplast preparations are commonly used for electrophysiological and omics studies, respectively. One of the most significant approaches in gurad cell analysis utilized about 350 million guard cell protoplasts from about 30,000 plants of the Arabidopsis wild type and the heterotrimeric G-protein $\alpha$ subunit mutant, gpal, which has ABA-hyposensitive stomata [JIN \& al. 2013]. This metabolomics analysis has triggered further research questions and directions [JIN \& al. 2013].

Recently, a non-targeted metabolomics utilizing gas chromatography mass spectrometry (GC-MS/MS) and liquid chromatography mass spectrometry (LC-MS/MS) were employed to identify metabolic signatures in response to ABA in B. napus guard cell protoplasts [ZHU \& al. 2017]. The identified 390 distinct metabolites in $B$. napus guard cells fell into diverse classes. Of these, 77 metabolites, comprising both primary and secondary metabolites were found to be significantly ABA responsive, including carbohydrates, fatty acids, glucosinolates, and flavonoids. Secondary metabolites, sinigrin, quercetin, campesterol, and sitosterol were selected for stomatal bioassays in Arabidopsis and B. napus. Fully expanded leaves from Arabidopsis or B. napus leaf pieces were excised and incubated with stomata opening solution under white light to promote stomatal opening. All these tested secondary metalolites were confirmed to regulate stomatal closure in Arabidopsis, B. napus or both species [ZHU \& al. 2017].

\section{Conclusion}

Considerable application of protoplast has been observed in the study of molecular mechanisms of plant growth and development due to the advantages of this in vivo cellular system [SHEEN, 2001; XING \& WANG, 2015; XING \& al. 2017]. Meanwhile, its potential in addressing physiological questions is also very promising, even though it could be challenging to interpret data obtained from protoplasts at physiological and organismal level. 
A general response and specific developmental processes may require different approaches and strategies. For example, identification of specific cell types where phosphorylation is activated may require that the protoplasts are to be isolated from the specific cell types with cellular responses evoked. Mitogen-activated protein kinase (MAPK) activation during stress response and immunity can be measured biochemically using kinase activity assays or immunoblot detection of phospho-MAPKs because the activation of MAPKs is global. However, their activation during specific growth and developmental processes is likely to be limited to a specific tissue or even a few cells.

The spatiotemporal expression of receptor-like kinases (RLKs) and their ligands provides a mechanism to define the response only in a specific group of cells. A single MAPK cascade composed of YDA-MKK4/MKK5-MPK3/MPK6 functions downstream of ER/ERLs to regulate both stomatal development and localized cell proliferation [LEE \& al. 2012; XU \& ZHANG, 2015]. In this case, the signaling specificity is a result of limited tissue/cell-specific expression of the peptide ligands of ER-family receptors [HUNT \& GRAY, 2009]. EPF1 and EPF2, which are expressed specifically within a subset of stomatal lineage cells, define the function of ER/ERL1/ERL2-YDA-MKK4/ MKK5MPK3/MPK6 pathway in stomatal development [HARA \& al. 2007; HUNT \& GRAY 2009; LEE \& al. 2012]. Protoplasts should then be isolated from sophisticatedly defined cell types.

Biological systems are composed of networks of interdependent components that integrate the system into a unified whole. We should keep in mind and in practice that after protoplast-based analysis, all results and hypotheses have to be verified at organism levels. 'The whole is something over and above its parts and not just the sum of them all' as stated by Greek physician Aristotle (384-322 B.C.).

\section{Notes on contributors}

Tim XING is an associate professor and a plant molecular biologist with a special interest in cell signaling and plant-microbe interactions. He teaches plant physiology, molecular plant development, and cell signaling.

Lining TIAN is a senior research scientist with a special interest in plant genetic engineering. He is also an adjunct professor in Western University and teaches plant biotechnology.

\section{References}

ASSMANN S. M., SIMONCINI L. \& SCHROEDER J. I. 1985. Blue light activates electrogenic ion pumping in guard cell protoplasts of Vicia faba. Nature. 318: 285-287.

BART R., CHERN M., PARK D. J., BARTLEY L. \& RONALD P. C. 2006. A novel system for gene silencing using sirnas in rice leaf and stem-derived protoplasts. Plant Methods 2: 13. doi:10.1186/1746-4811-2-13.

BIRNBAUM K., SHASHA D. E., WANG J. Y., JUNG J. W., LAMBERT G. M., GALBRAITH D. W. \& BENFEY P. N. 2003. A gene expression map of the Arabidopsis root. Science. 302: 1956-1960.

EDWARDS G. E., FRANCESCHI V. R. \& VOZNESENSKAYA E. V. 2004. Single-cell C 4 photosynthesis versus the dual-cell (Kranz) paradigm. Annu. Rev.Plant Biol. 55: 173-196.

DEEKEN R., GEIGER D., FROMM J., KOROLEVA O., ACHE P., LANGENFELD-HEYSER R., SAUER N., MAY S. T. \& HEDRICH R. 2002. Loss of AKT2/3 potassium channel affects sugar loading into the phloem of Arabidopsis. Planta. 216: 334-344.

EULGEM T., RUSHTON P. J., SCHMELZER E., HAHLBROCK K. \& SOMSSICH I. E. 1999. Early nuclear events in plant defense signalling: rapid gene activation by WRKY transcription factors. EMBO J. 18: 4689-4699. 
FARACO M., DI SANSEBASTIANO G. P., SPELT K., KOES R. E. \& QUATTROCCHIO F. M. 2011. One protoplast is not the other! Plant Physiol. 156: 474-478.

FEIJÓ J. A., SAINHAS J., HOLDAWAY-CLARKE T., CORDIERO M. S., KUNKEL J. G. \& HEPLER P. K. 2001. Cellular oscillations and the regulation of growth: the pollen tube paradigm. BioEssays. 23: 86-94.

GALUN E. 1981. Plant protoplasts as physiological tools. Annu. Rev. Plant Physiol. 32: 237-266.

GOWIK U. \& WESTHOFF P. 2011. The path from $\mathrm{C}_{3}$ to $\mathrm{C}_{4}$ photosynthesis. Plant Physiol. 155: 56-63.

HARA K., KAJITA R., TORII K. U., BERGMANN D. C. \& KAKIMOTO T. 2007. The secretory peptide gene EPF1 enforces the stomatal one-cell-spacing rule. Genes Dev. 21: 1720-1725.

HAFKE J. B., FURCH A. C., REITZ M. U. \& VAN BEL A. J. 2007. Functional sieve element protoplasts. Plant Physiol. 145: 703-711.

HEPLER P. K., VIDALI L. \& CHEUNG A. Y. 2001. Polarized cell growth in higher plants. Annu. Rev. Cell Dev. Biol. 17: 159-187.

HUBER S. C. \& EDWARDS G. E. 1975. $\mathrm{C}_{4}$ photosynthesis: light dependent $\mathrm{CO}_{2}$ fixation by mesophyll cells, protoplast and protoplast extracts of Digitalia sanguinalis. Plant Physiol. 55: 834-844.

HUBER S. C. \& EDWARDS O. E. 1975. An evaluation of some parameters required for the enzymatic isolation of cells and protoplasts with $\mathrm{CO}_{2}$ fixation capacity from $\mathrm{C}_{3}$ and $\mathrm{C}_{4}$ grasses. Physiol. Plant. 35: 203-209.

HUNT L. \& GRAY J. E. 2009. The signaling peptide EPF2 controls asymmetric cell divisions during stomatal development. Curr. Biol. 19: 864-869.

JIN X., WANG R. S., ZHU M., JEON B. W., ALBERT R., CHEN S. \& ASSMANN S. M. 2013. Abscisic acidresponsive guard cell metabolomes of Arabidopsis wild-type and Gpal G-protein mutants. Plant Cell. 25: 4789-4811.

KIM T. H., BÖHMER M., HU H., NISHIMURA N. \& SCHROEDER J. I. 2010. Guard cell signal transduction network: advances in understanding abscisic acid, $\mathrm{CO}_{2}$, and $\mathrm{Ca}^{2+}$ signaling. Annu. Rev. Plant Biol. 61: 561-591.

KU S. B., GUTIERREZ M., KANAI R. \& EDWARDS G. E. 1974. Photosynthesis in mesophyll protoplasts and bundle sheath cells of $\mathrm{C}_{4}$ plants: chlorophyll and Hill reaction studies. Z PfIanzenphysiol. 72: 320-327.

KÜHN C. 2003. A Comparison of the sucrose transporter systems of different plant species. Plant Biol. 5: 215-232.

LACOMBE B., PILOT G., MICHARD E., GAYMARD F., SENTENAC H. \& THIBAUD J. B. 2000. A shakerlike $\mathrm{K}^{+}$channel with weak rectification is expressed in both source and sink phloem tissues of Arabidopsis. Plant Cell. 12: 837-851.

LEE J. S., KUROHA T., HNILOVA M., KHATAYEVICH D., KANAOKA M. M., MCABEE J. M., SARIKAYA M., TAMERLER C. \& TORII K. U. 2012. Direct interaction of ligand-receptor pairs specifying stomatal patterning. Genes Dev. 26: 126-136.

OUTLAW JR. W. H. 2003. Integration of cellular and physiological functions of guard cells. CRC Crit. Rev. Plant Sci. 22: 503-529.

PATRICK J. W. 2013. Does Don Fisher's high-pressure manifold model account for phloem transport and resource partitioning? Front. Plant Sci. 4: 184.

PILET P. E. 1985. The physiological properties of plant protoplasts. Springer-Verlag, Berlin-Heidelberg-New York-Tokyo.

PINA C., PINTO F., FEIJÓ J. A. \& BECKER J. D. 2005. Gene family analysis of the Arabidopsis pollen transcriptome reveals novel biological implications for cell growth and division control and gene expression regulation. Plant Physiol. 138: 744-756.

SHEEN J. 2001. Signal transduction in maize and Arabidopsis mesophyll protoplasts. Plant Physiol. 127: 1466-1475.

SLEWINSKI T. L., ZHANG C. \& TURGEON R. 2013. Structural and functional heterogeneity in phloem loading and transport. Front. Plant Sci. 4: 244.

TALLMAN G. 2006. Guard cell protoplasts: isolation, culture, and regeneration of plants. IN: LOYOLAVARGAS V. M. \& VÁZQUEZ-FLOTA F. (ed.). Methods in Molecular Biology, Volume 318: Plant Cell Culture Protocols, second edition, Humana Press Inc., Totowa, NJ: 233-252.

TAVARES B., DIAS P. N., DOMINGOS P., MOURA T. F., FEIJÓ J. A. \& BICHO A. 2011. Calcium-regulated anion channels in the plasma membrane of Lilium longiflorum pollen protoplasts. New Phytol. 192: 45-60.

TURGEON R. 2010. The puzzle of phloem pressure. Plant Physiol. 154: 578-581.

TURGEON R. \& WOLF S. 2009. Phloem transport: cellular pathways and molecular trafficking. Annu. Rev. Plant Biol. 60: 207-221.

VAN DEN BERG C., WILLEMSEN V., HAGE W., WEISBEEK P. \& SCHERES B. 1995. Cell fate in the Arabidopsis root meristem determined by directional signalling. Nature. 378: 62-65.

XING T. \& WANG X. J. 2015. Protoplasts in plant signaling analysis: moving forward in the omics era. Bot. 93: 325-332. 
XING T., LI X. Q., LAROCHE A., TIAN L. N., TUBEI K. \& WANG X. J. 2017. Protoplasts in the analysis of early plant-pathogen interactions: current applications and perspectives. Eur. J. Plant Pathol. 149: 1001-1010.

XU J. \& ZHANG S. 2015. Mitogen-activated protein kinase cascades in signaling plant growth and development. Trends Plant Sci. 20: 56-64.

YAMAZAKI D., YOSHIDA S., ASAMI T. \& KUCHITSU. K. 2003. Visualization of abscisic acid perception sites on the plasma membrane of stomatal guard cells. Plant J. 35: 129-139.

ZHAI Z., SOOKSANGUAN T. \& VATAMANIUK O. K. 2009. Establishing RNA interference as a reversegenetic approach for gene functional analysis in protoplasts. Plant Physiol. 149: 642-652.

ZHANG Y., SU J., DUAN S., AO Y., DAI J., LIU J., WANG P., LI Y., LIU B., FENG D., WANG J. \& WANG H. 2011. A highly efficient rice green tissue protoplast system for transient gene expression and studying light/chloroplast-related processes. Plant Methods. 30. doi: 10.1186/1746 -4811-7-30.

ZHU M. \& ASSMANN S. M. 2017. Metabolic signatures in response to abscisic acid (ABA) treatment in Brassica napus guard cells revealed by metabolomics. Sci. Rep. 7: 12875 doi: 10.1038/s41598-01713166-w.

ZHU M., JEON B. W., GENG S., YU Y., BALMANT K., CHEN S. \& ASSMANN S. M. 2016. Preparation of epidermal peels and guard cell protoplasts for cellular, electrophysiological, and -omics assays of guard cell function. IN: BOTELLA J. \& BOTELLA M. (ed.). Methods in Molecular Biology, Volume 1363: Plant Signal Transduction, Humana Press Inc., New York, NY: 89-121.

How to cite this article:

XING T. \& TIAN L. 2018. Protoplast as a tool to address questions in plant physiology. J. Plant Develop. 25: 99-105. https://doi.org/10.33628/jpd.2018.25.1.99 